\title{
Trace Element Levels, Cytokine Profile and Immune Activation Status in Plasma among Repeat Blood Donors with Asymptomatic HIV-1, HBV and HCV Infection
}

\author{
Alice Verghese ${ }^{1 *}$, Som Nath Singh², Debasish Chattopadhya ${ }^{3}$ \\ ${ }^{1}$ Centre for AIDS and Related Diseases, National Centre for Disease Control, Delhi, India \\ ${ }^{2}$ Defence Institute of Physiology and Allied Sciences, Delhi, India \\ ${ }^{3}$ Department of Microbiology, Faculty of Medicine and Health Sciences, SGT University, Gurgaon, India \\ Email: *alice_verghese@yahoo.com
}

How to cite this paper: Verghese, A., Singh, S.N. and Chattopadhya, D. (2017) Trace Element Levels, Cytokine Profile and Immune Activation Status in Plasma among Repeat Blood Donors with Asymptomatic HIV-1, HBV and HCV Infection. Journal of Biosciences and Medicines, 5, 75-94.

https://doi.org/10.4236/jbm.2017.59008

Received: August 21, 2017

Accepted: September 16, 2017

Published: September 19, 2017

Copyright $\odot 2017$ by authors and Scientific Research Publishing Inc. This work is licensed under the Creative Commons Attribution International License (CC BY 4.0).

http://creativecommons.org/licenses/by/4.0/

\section{(c) (i) Open Access}

\begin{abstract}
Imbalance of essential trace elements viz. Zinc, Selenium, Iron, Copper and Magnesium has been reported to influence disease course in HIV-1, HBV and HCV infections by altering immune status. A study was taken up to examine plasma levels of Th1 (IFN- $\gamma$ and IL-2) and Th2 (IL-4 and IL-10) categories of cytokines and immune activation markers (TNF- $\alpha$, TNFR I and TNFR II) in an asymptomatic group of HIV-1, HBV and HCV infected blood donors in relation to trace elements. Plasma levels of $\mathrm{Zn}$, Se and $\mathrm{Mg}$ were depressed in all the three groups of blood donors $(\mathrm{P}<0.001$ for all). Levels of $\mathrm{Cu}$ and $\mathrm{Fe}$ were depressed in HIV-1 infection $(\mathrm{P}<0.001$ for both), but elevated in HBV and HCV infections $(\mathrm{P}<0.015$ and $<0.001$ for $\mathrm{Cu}$ and Fe in HBV and HCV infections respectively). IL-2 and IFN- $\gamma$ were depressed in all the three groups of blood donors $(\mathrm{P}<0.001)$. IL-4 and IL-10 levels were elevated in HBV and HCV infections $(\mathrm{P}<0.001$ for both). Immune activation markers were elevated in all the three groups of blood donors $(\mathrm{P}<0.001$ for all). HIV-1 infection showed positive correlations between $\mathrm{Cu}$ and IL-2, $\mathrm{Zn}$ and IFN- $\gamma$, and in HBV infection while positive correlations were found between $\mathrm{Mg}$ and TNFR I and TNFR II and Se with TNFR II. HCV infection showed a positive correlation between Se and IFN- $\gamma(\mathrm{P}<0.001), \mathrm{Mg}$ and IL-4 (P = 0.02), Fe and IL-10 $(\mathrm{P}<0.01)$. The present study reveals possible relationship between trace element level alterations and alterations in cytokine and immune activation levels in HIV-1, HBV and HCV infection.
\end{abstract}

\section{Keywords}

HIV-1, HBV, HCV, Trace Elements, Cytokines, Immune Activation 


\section{Introduction}

High prevalence of Human immune deficiency virus type 1 (HIV-1), Hepatitis B virus (HBV) and Hepatitis $\mathrm{C}$ virus (HCV) among blood donors has been recorded globally [1]. In the city of Delhi, the overall prevalence in blood donors has been reported to range from $0.28 \%$ to $0.30 \%$ for HIV-1, $1.15 \%$ to $1.33 \%$ for $\mathrm{HBV}$ and $0.57 \%$ to $0.67 \%$ for HCV respectively [2]. Studies indicate that an imbalance in T helper type 1 (Th1) and T helper type 2 (Th2) cytokine profile is associated with disease progression in infections due to HIV-1 [3], HBV [4] and HCV [5]. Further, studies have shown that changes in the intracellular environment induced by alterations in trace element status can cause immune dysfunction [6]. There are separate reports on cytokine alterations in HIV-1, HBV and HCV infections and that on trace element alterations in these infections [7] [8] [9]. However, there is hardly any report on relationship between trace element status and cytokine profile in HIV-1, HBV and HCV infections in same group of individuals. The present work aimed to study the impact of changes in a wide range of trace elements i.e. Zinc, Selenium, Iron, Copper and Magnesium (Zn, $\mathrm{Se}, \mathrm{Fe}, \mathrm{Cu}, \mathrm{Mg}$ ) on the status of immune activation and cytokine profile in an asymptomatic group of blood donors infected with HIV-1, HBV and HCV.

\section{Materials and Methods}

The project was approved by institutional review board including ethical clearance. The donors were explained the purpose of the study. Written consent for the study was obtained from the donors using a predesigned consent form in local language. During the period from July to December 2016, all the major blood banks including the private ones in the national capital territory of Delhi were requested to refer the blood donors found seropositive for HIV, HBV and HCV at their centres to the Centre for AIDS and Related Diseases, National Centre for Disease Control (NCDC). A total of 120 blood donors (all males), 40 each confirmed to be seropositive for HIV-1, HBV and HCV at NCDC were selected for the study. The period between detection of seropositivity for HIV-1, HBV and HCV in the blood banks referring the donors and confirmation of the same at Centre for AIDS and Related Diseases department, NCDC was considered duration of infection since diagnosis. In addition, since the donors were repeat donors donating blood at intervals of 4 - 8 months, whenever a seropositive blood donor was referred by a blood bank to our centre, test results for HIV, HBV and $\mathrm{HCV}$ at preceding blood bank attended by the seropositive donors were checked from the records available with blood banks to confirm seronegativity at the time of preceding donation. Forty, age and socioeconomically matched male blood donors seronegative for HIV-1, HBV and HCV infections and donating at the same blood banks were included as controls.

\subsection{Epidemiological Information}

A confidential interview was taken from the donors regarding age, marital status, 
frequency of blood donation (for preceding one year), HIV related risk behaviours in terms of frequency (per week) of unprotected sex with heterosexual and/or homosexual partners as well as number of sex partners (for preceding one year). History of other risk factors viz. parenteral drug abuse as well as receipt of blood/ blood products were also obtained from the donors.

\subsection{History of Dietary Intake, Alcohol Consumption and HBV Vaccination Coverage}

A quantitative assessment of dietary intake was conducted by recall procedure for immediate past three typical days employing a food frequency questionnaire. Average daily intakes of total energy and protein were calculated as per Indian Council of Medical Research (ICMR) guidelines based on the quantities of various categories of raw food materials consumed as described earlier [10]. History regarding consumption of alcoholic drinks was elicited in terms of sessions/week (during preceding one year) while no consideration was given to brand or quantity of alcoholic drink consumed. The donors were enquired about the vaccination status against HBV from the records available with them.

\subsection{Anthropometric Assessment and Clinical Assessment}

Height $( \pm 0.1 \mathrm{~cm})$ and weight $( \pm 0.1 \mathrm{Kg})$ were measured using standard techniques and body mass index (BMI) calculated by the formula weight $(\mathrm{kg}) /$ height $\left(\mathrm{m}^{2}\right)$ [11]. The seropositive cases were examined clinically by clinician at reference centre to determine the stage of illness. The cases were ruled out for any metabolic disorder, malignancy or immunosuppressive therapy.

\subsection{Laboratory Studies}

Fasting blood was collected and distributed as about $8 \mathrm{ml}$ in plain sterile tube to yield serum for estimation of enzyme markers, serological assays for HIV-1, HBV and HCV infections, while about $4 \mathrm{ml}$ of blood was distributed ethylene-diamine-tetra-acetic acid (EDTA) vial for routine haemoglobin, peripheral CD4 T lymphocyte count, cytokine, immune markers and trace element analysis.

\subsection{Diagnosis of HIV-1, HBV and HCV Infection}

Diagnosis of HIV-1 infection was based on commercial Enzyme- Linked Immunosorbent Assay (ELISA) test carried out at various blood banks in the city of Delhi and confirmatory western blot test carried out at AIDS Reference Centre, National Centre for Disease control (formerly National Institute of Communicable Diseases), Delhi [12]. HBV infection was diagnosed by detection of any of the three markers viz. hepatitis B surface antigen (HBsAg), antibody to hepatitis B surface antigen (anti-HBs), antibody to hepatitis B core antigen (anti-HBc) employing commercial ELISA kits while diagnosis of HCV infection was carried out by detection of anti-HCV antibodies employing the ELISA and Recombinant Immunoblot Assay (RIBA) (Abott laboratories, North Chicago, IL, USA) [10]. All the donors and seronegative controls were screened for syphilis using com- 
mercial Treponema Pallidum Haemagglutination (TPHA) kit (Fujirebio, Japan) to eliminate co-infection with syphilis [13].

\subsection{Estimation of Enzyme Markers}

Estimation of three enzyme markers as indices of liver function including alanine aminotransferase (ALT), aspartate aminotransferase (AST), alkaline phosphatase (ALP) and total bilirubin in serum were carried out using auto-analyzer (Hitachi 912, Hitachi Ltd., Japan). Estimation of serum levels of albumin were carried out by techniques as described earlier [10]. Upper limit of normal values for ALT, AST, ALP and bilirubin was accepted as $55 \mathrm{U} / \mathrm{L}, 48 \mathrm{U} / \mathrm{L}, 115 \mathrm{U} / \mathrm{L}$ and $1.2 \mathrm{mg} / \mathrm{dL}$ respectively [14].

\subsection{Enumeration of CD4 + T Lymphocytes}

Enumeration of peripheral CD4 + T lymphocytes was done by flow cytometry. In brief, a standard flow cytometry method with lysed whole blood and a panel of two color combinations of fluorescein isothyocyanate and phycoerythrinconjuagated monoclonal antibody regents obtained from a single manufacturer (Becton-Dickinson, San Jose, California) were used to determine the expression of each antigen or antigen combination as described earlier [15].

\subsection{Estimation of Trace Elements}

Estimation of trace elements viz., $\mathrm{Zn}, \mathrm{Se}, \mathrm{Fe}, \mathrm{Cu}$ and $\mathrm{Mg}$ in plasma was carried out using Flame Atomic Absorption Spectrophotometer (FAAS) (Thermo Electron Corporation, UK M6 Spectro with integrated software SOLAAR AA) as described earlier [16]. Commercially available standard solutions of trace elements from commercial source (Merck Private limited, Germany, concentrations 1000 $\mathrm{ppm}$ ) were used to prepare suitable calibration curve for calculating trace element concentrations in plasma. All the working standard solutions were prepared in $10 \mathrm{mmol} / \mathrm{L}$ nitric acid. Plasma samples were diluted 100 fold for magnesium, 10 fold for copper, iron, selenium and zinc in $10 \mathrm{mmol} / \mathrm{L}$ nitric acid and then aspirated directly in FAAS. A blank was used for setting of zero absorbance of spectrophotometer.

\subsection{Detection of Th1, Th2 Cytokines and Immune Activation Markers}

Levels of T helper type1 (Th1) cytokines viz. interleukin-2 (IL-2) and gamma interferon (IFN- $\gamma$ ) and T helper type 2 (Th2) cytokines viz., Interleukin-4 (IL-4) and Interleukin-10 (IL-10) were measured in plasma using commercial ELISA kits (R\&D Systems, Minneapolis, MI, USA) with sensitivity limits of $0.06 \mathrm{pg} / \mathrm{ml}$, $8 \mathrm{pg} / \mathrm{ml}, 0.22 \mathrm{pg} / \mathrm{ml}$ and $0.17 \mathrm{pg} / \mathrm{ml}$ for IL-2, IFN- $\gamma$, IL-4 and IL-10 respectively. Plasma levels of immune activation markers viz., tumour necrosis factor alpha (TNF- $\alpha$ ), tumour necrosis factor alpha receptor type l (TNFR p 55) and type 11 (TNFR p 75) were measured using commercial ELISA kits from source as above with sensitivity levels of $0.49 \mathrm{pg} / \mathrm{ml}, 1.2 \mathrm{pg} / \mathrm{ml}$ and $2.3 \mathrm{pg} / \mathrm{ml}$ respectively. Coef- 
ficient variation for all of these assays was found to be less than $10 \%$. Readings below detection range were assigned zero values.

\subsection{Statistical Analysis}

Statistical analysis was carried out employing SPSS version 20. Characteristics of blood donors as assessed at enrolment were compared using $\chi^{2}$ test for categorical variables and one way ANOVA for continuous variables with normal distribution while continuous variables not following normal distribution were compared by Kruskal Wallis test followed by multiple comparison using Mann Whitney test. $\mathrm{P}$ value $<0.05$ was considered as statistically significant and it was adjusted for multiple comparisons. Fisher's exact test was used in which any of the expected cell frequency was less than five. Correlation of cytokine levels with trace element levels was evaluated by Spearman rank correlation test (due to lack of normal distribution in certain parameters).

\section{Results}

\subsection{Demographic Profile, Risk Behaviour, Dietary Intake, CD4 Counts and Liver Enzyme Profile of the HIV-1, HBV and HCV Infected Donors}

All the seropositive donors were males and unmarried belonging to the age group 24 - 33 years without any significant difference compared to seronegative blood donor control (mean \pm SD for HIV-1, HBV, HCV and seronegative control as $29.2 \pm 3.3,30.5 \pm 2.6,29.2 \pm 2.9,30.0 \pm 2.5$ respectively). The mean duration between the preceding seronegative donation and detection of seropositivity for HIV-1, HBV and HCV in infected blood donors and seronegative donors ranged between 4 - 6 months with mean \pm SD for HIV-1, HBV and HCV as 5.1 $\pm 0.8,4.57 \pm 0.5,5.0 \pm 0.8$ and $4.8 \pm 0.6$ respectively (data not shown in table). Magnitude of exposure to unprotected sex with female CSWs could be elicited most in HIV-1 infected donors followed by HBV and HCV (Table 1). However none of the donors in any category gave history of other HIV related risk behaviour like parenteral drug abuse or receipt of blood transfusion. The proportion of individuals consuming alcohol was comparable between HIV-1, HBV and $\mathrm{HCV}$ infected donors as well as seronegative controls. Moreover the frequency of alcohol consumption was comparable between HIV-1, HBV, HCV and seronegative control groups (Table 1 ).

There was no alteration in CD4 T + lymphocyte count in all the subgroups of seropositive donors. On the other hand liver enzymes showed marginal elevation in all the subgroups of seropositive donors although the levels were comparable to seronegative controls. Serum bilirubin levels were unaltered in all the subgroups of seropositive donors. Energy intake and protein intake in all the three subgroups of seropositive donors were comparable to seronegative blood donor controls. There was no difference in the status of BMI and serum levels of albumin among the various groups of donors and controls (Supplementary Table 1). None of the donors received full or partial HBV vaccination. 
Table 1. HIV related risk behaviour and alcohol intake in HIV-1, HBV and HCV infected blood donors.

\begin{tabular}{|c|c|c|c|c|c|c|c|}
\hline & & & $\begin{array}{l}\text { HIV-1 } \\
(\mathrm{n}=40)\end{array}$ & $\begin{array}{c}\text { HBV } \\
(\mathrm{n}=40)\end{array}$ & $\begin{array}{c}\mathrm{HCV} \\
(\mathrm{n}=40)\end{array}$ & $\begin{array}{l}\text { Control } \\
(\mathrm{n}=40)\end{array}$ & $\begin{array}{c}\text { Statistical } \\
\text { Comparisons }\end{array}$ \\
\hline & & & Group I & Group II & Group III & Group IV & \\
\hline \multirow{5}{*}{$\begin{array}{l}\mathrm{H} / \mathrm{O} \text { unprotected sex } \\
\text { with female } \mathrm{CSW}^{\star}\end{array}$} & $\begin{array}{l}\text { Positive } \\
\text { history }\end{array}$ & No (\%) & $31(77.5 \%)$ & $16(40 \%)$ & $9(22.5 \%)$ & NA & $\begin{array}{l}\chi^{2}=26.86 \\
P<0.000\end{array}$ \\
\hline & \multirow{2}{*}{$\begin{array}{l}\text { Frequency of } \\
\text { Exposure/week }\end{array}$} & Range $^{* *}$ & $1-3$ & $0-1$ & $0-1$ & NA & \multirow{2}{*}{$\begin{array}{l}f=23.94 \\
P<0.000\end{array}$} \\
\hline & & Mean $\pm \mathrm{SD}^{\star *}$ & $2.1 \pm 0.8$ & $1.0 \pm 0$ & $1.0 \pm 0$ & NA & \\
\hline & \multirow{2}{*}{ No. of partners } & Range $^{* *}$ & $4-6$ & $2-3$ & $2-3$ & NA & \multirow{2}{*}{$\begin{array}{l}f=77.56 \\
P<0.000\end{array}$} \\
\hline & & Mean $\pm \mathrm{SD}^{* *}$ & $4.5 \pm 0.8$ & $2.4 \pm 0.5$ & $2.1 \pm 0.3$ & & \\
\hline \multirow{3}{*}{$\begin{array}{l}\text { Consumption of } \\
\text { alcoholic drink }^{*}\end{array}$} & $\begin{array}{l}\text { Positive } \\
\text { history }\end{array}$ & No (\%) & $15(37.5)$ & $14(35)$ & $12(30)$ & $10(25)$ & \\
\hline & \multirow{2}{*}{ Sessions/week } & Range $^{* *}$ & $2-4$ & $2-3$ & $2-3$ & $1-3$ & \multirow{2}{*}{$\begin{array}{c}f=0.63 \\
P=\text { NS (0.55) }\end{array}$} \\
\hline & & Mean $\pm \mathrm{SD}^{\star *}$ & $2.1 \pm 0.38$ & $2.2 \pm 0.46$ & $2.2 \pm 0.45$ & $2.1 \pm 0.8$ & \\
\hline
\end{tabular}

${ }^{\star}$ During one year of pre-enrolment period; ${ }^{\star *}$ Calculated for the donors with positive history only; None of the donors gave history of parenteral drug abuse or receipt of blood transfusion.

\subsection{Plasma Trace Element Levels in HIV-1, HBV and HCV Infected Blood Donors}

There was significant depression in plasma levels of $\mathrm{Zn}, \mathrm{Se}, \mathrm{Fe}, \mathrm{Cu}$ and $\mathrm{Mg}$ in the group of blood donors infected with HIV-1 ( $<0.001$ for all comparisons). In case of HBV and in HCV infected blood donors, plasma levels of $\mathrm{Cu}$ and Fe were significantly elevated as compared to controls. However, $\mathrm{Zn}$, Se and $\mathrm{Mg}$, levels in plasma were significantly depressed in both HBV and HCV infected blood donors compared to seronegative controls $(\mathrm{P}<0.001$ for all comparisons) (Table 2).

\subsection{Plasma Cytokine Levels and Immune Activation Markers in HIV-1, HBV and HCV Infected Blood Donors}

The plasma concentrations of Th1 type of cytokines i.e., IL- 2 and IFN- $\gamma$, were significantly decreased in all the three asymptomatic infected groups i.e., HIV-1, HBV and HCV $(\mathrm{P}<0.001)$. On the other hand, levels of Th2 type cytokines viz. IL-4 and IL-10 remained unaltered compared to control groups in case of HIV-1 $(\mathrm{P}=0.39, \mathrm{P}=0.42$ respectively). But in case of $\mathrm{HBV}$ and HCV, Th2 type of cytokines i.e., IL-4 and IL-10 were found to be significantly elevated $(\mathrm{P}<0.001$ for all comparisons). Levels of three immune activation markers studied viz. TNF $\alpha$, TNFR 1 and TNFR II were significantly increased in all the three groups of donors compared to seronegative controls $(\mathrm{P}<0.001)$ (Table 3$)$.

\subsection{Correlation of Trace Element with Cytokines and Immune Activation Markers in HIV-1, HBV and HCV Infected Blood Donors}

Correlation of trace element status with plasma cytokine levels in HIV-1, HBV and HCV infected blood donors showed that in case of HIV-1 infection a 
Table 2. Plasma levels (mean $\pm \mathrm{SD}$ ) of trace elements in blood donors with HIV-1, HBV and HCV infections.

\begin{tabular}{ccccc}
\hline \multicolumn{3}{c}{ Blood donor groups } & Control \\
\hline $\begin{array}{c}\text { Trace element } \\
\text { level }\end{array}$ & $\begin{array}{c}\text { HIV-1 }(\mathrm{n}=40) \\
\text { Group I }\end{array}$ & $\begin{array}{c}\text { HBV }(\mathrm{n}=40) \\
\text { Group II }\end{array}$ & $\begin{array}{c}\text { HCV }(\mathrm{n}=40) \\
\text { Group III }\end{array}$ & $\begin{array}{c}(\mathrm{n}=40) \\
\text { Group IV }\end{array}$ \\
\hline $\mathrm{Zn}(\mu \mathrm{g} / \mathrm{dl})$ & $50.78 \pm 4.53^{*}$ & $54.28 \pm 12.25^{*}$ & $54.40 \pm 3.12^{*}$ & $83.08 \pm 12.48$ \\
$\mathrm{Se}(\mu \mathrm{g} / \mathrm{dl})$ & $49.75 \pm 14.60^{*}$ & $63.28 \pm 12.70^{*}$ & $51.43 \pm 7.94^{*}$ & $93.55 \pm 9.08$ \\
$\mathrm{Fe}(\mu \mathrm{g} / \mathrm{dl})$ & $63.52 \pm 8.94^{*}$ & $181.76 \pm 16.92^{* *}$ & $183.63 \pm 13.55^{* *}$ & $105.58 \pm 25.50$ \\
$\mathrm{Cu}(\mu \mathrm{g} / \mathrm{dl})$ & $67.23 \pm 12.98^{*}$ & $95.25 \pm 10.60^{* *}$ & $128.85 \pm 16.89^{* *}$ & $89.63 \pm 12.46$ \\
$\mathrm{Mg}(\mathrm{mg} / \mathrm{dl})$ & $1.16 \pm 0.27^{*}$ & $1.57 \pm 0.50^{*}$ & $1.35 \pm 0.21^{*}$ & $2.03 \pm 0.62$ \\
\hline
\end{tabular}

*Significant depression $(\mathrm{P}<0.05)$ compared to controls; ${ }^{*}$ Significant elevation $(\mathrm{P}<0.05)$ compared to controls; Multiple comparisons between the groups(by ANOVA): Cu: Overall $\mathrm{P}<0.001$; II vs. IV $\mathrm{P}<0.03$; rest all comparisons $<0.001$; Fe: Overall $\mathrm{P}<0.001$ : II vs. III $\mathrm{P}=\mathrm{NS}(0.63)$; rest all comparisons $<0.001$; Mg: Overall $<0.001$; I vs. III $\mathrm{P}=\mathrm{NS}(0.12)$; rest all comparisons $<0.001$; Se: Overall $\mathrm{P}<0.001$; I vs. III $\mathrm{P}=\mathrm{NS}$ (0.53): rest all comparisons $<0.001 ; \mathrm{Zn}$ : Overall $\mathrm{P}<0.001$; I vs. II $\mathrm{P}=\mathrm{NS}(0.10)$; II vs. III $<0.95$; rest all comparisons $<0.001$.

Table 3. Plasma levels (mean \pm SD) of cytokines and immune activation markers in blood donors with HIV-1, HBV and HCV infection.

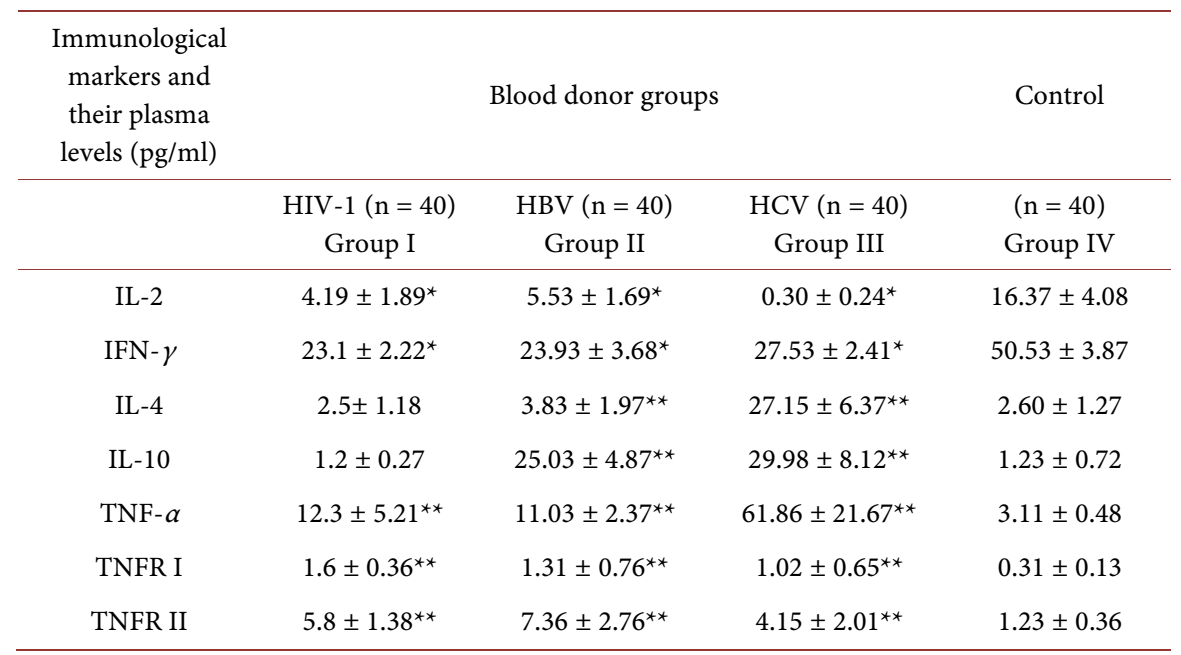

*Significant depression $(\mathrm{P}<0.05)$ compared to controls; ${ }^{*}$ Significant elevation $(\mathrm{P}<0.05)$ compared to controls; Multiple comparisons between the groups(by ANOVA): IL2: Overall P $<0.001$; all comparisons $<0.001$; IFN $-\gamma$. Overall $\mathrm{P}<0.001$; I vs. II $\mathrm{P}=\mathrm{NS}(0.23)$; rest all comparisons $\mathrm{P}<0.001$; IL-4: Overall $\mathrm{P}<$ 0.001; I vs. IV $\mathrm{P}=\mathrm{NS}(0.80)$; rest all comparisons $\mathrm{P}<0.001$; IL-10: Overall $\mathrm{P}<0.001$; I vs. IV $\mathrm{P}=\mathrm{NS}(0.85)$; rest all comparisons $\mathrm{P}<0.001$; TNF $\alpha$ : Overall $\mathrm{P}<0.001$; I vs. II $\mathrm{P}=\mathrm{NS}(0.14)$; rest all comparisons $\mathrm{P}<$ 0.001; TNFR I: Overall P < 0.001; I vs. II P $=$ NS (0.12); rest all comparisons $<0.001$; TNFR II: Overall $\mathrm{P}<$ 0.001 ; all comparisons $\mathrm{P}<0.001$.

marginal but significant positive correlation was found between $\mathrm{Cu}$ level and IL-2, $\mathrm{Zn}$ and IFN- $\gamma(\mathrm{r}=0.33, \mathrm{P}=0.03$ for both $\mathrm{Cu}$ and $\mathrm{Zn}$ ) (Figure 1 (a) and Figure 1(b)). However, no correlation could be demonstrated between the rest of the trace elements studied viz. Fe, Mg and Se with any of the Th1 or Th2 category of cytokines (Supplementary Table 2(a)). Correlation of trace element levels with the immune activation markers in HIV-1 infection showed a significant negative correlation between $\mathrm{Zn}$ and TNFR $1(\mathrm{r}=-0.31, \mathrm{P}=0.04)$ (Figure $1(\mathrm{c})$ ). 


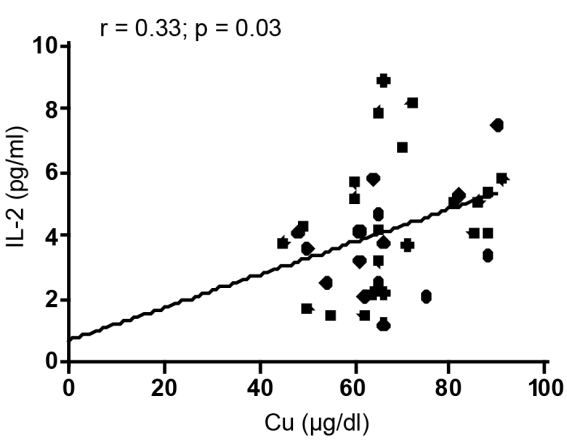

(a)

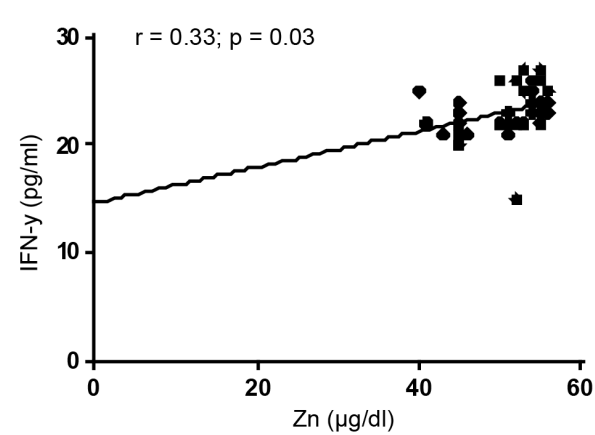

(b)

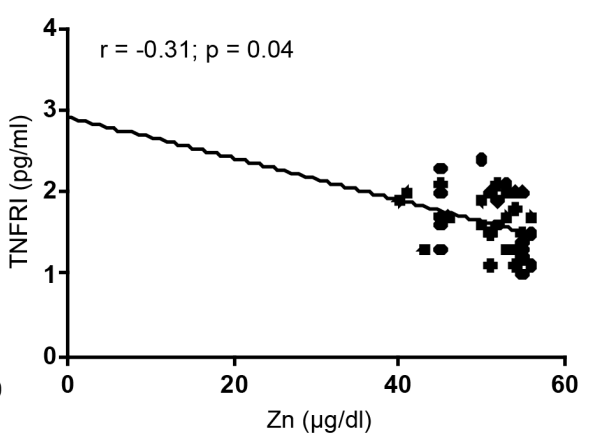

(c)

Figure 1. (a): Spearman rank correlation between plasma levels of copper $(\mathrm{Cu})$ and interleukin 2(IL-2) in HIV-1 infected blood donors $(\mathrm{n}=40 ; \mathrm{r}=0.33$; $\mathrm{P}=0.03)$; (b): Spearman rank correlation between plasma levels of Zinc $(\mathrm{Zn})$ and interferon gamma (IFN- $\gamma$ ) in HIV-1 Infected blood donors $(n=40 ; r=0.33, P=0.03)$; $(c)$ : Spearman rank correlation between plasma levels of Zinc ( $\mathrm{Zn})$ tumour necrosis factor type-1 (TNFR I) in HIV -1 infected blood donors $(n=40 ; r=-0.31, P=0.04)$.

In case of HBV infected blood donors significant positive correlations were found between Mg and TNFR $1(\mathrm{r}=0.33, \mathrm{P}=0.04)$ and both $\mathrm{Mg}$ and Se with immune marker TNFR II ( $\mathrm{r}=0.33, \mathrm{P}=0.04 ; \mathrm{r}=0.42, \mathrm{P}=0.006$ respectively) (Figures 2(a)-(c)). No correlation could be demonstrated in HBV infected blood donors between the levels of various trace elements and any of the Th1 and Th2 types of cytokines (Supplementary Table 2(b)).

In HCV infected blood donors samples, there was a positive correlation between Se andIFN- $\gamma(\mathrm{r}=0.60, \mathrm{P}<0.001), \mathrm{Mg}$ with IL-4 $(\mathrm{r}=0.36, \mathrm{P}=0.02)$, Fe with IL-10 ( $\mathrm{r}=0.37, \mathrm{P}=0.01)$ (Figures $3(\mathrm{a})-(\mathrm{c}))$. However, a negative correlation was demonstrated between $\mathrm{Cu}$ level with Th2 type of cytokines IL-4 and IL-10 ( $\mathrm{r}=-0.39, \mathrm{P}=0.01, \mathrm{r}=-0.32, \mathrm{P}=0.03$ respectively) (Figure $3(\mathrm{~d})$ ); Figure $3(e))$ and between Se and IL4 $(r=-0.31, P=0.04)$ (Figure $3(f)$ ). No other correlation could be demonstrated between trace elements with cytokines and immune activation markers studied in case of HCV infection (Supplementary Table 2(c)).

\section{Discussion}

The HIV-1 seropositive donors in the present study showed higher magnitude of exposure to unsafe sex compared to HBV and HCV positive donors. However, 


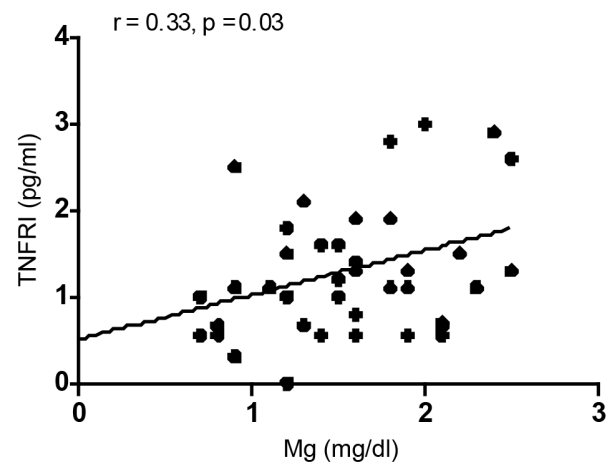

(a)

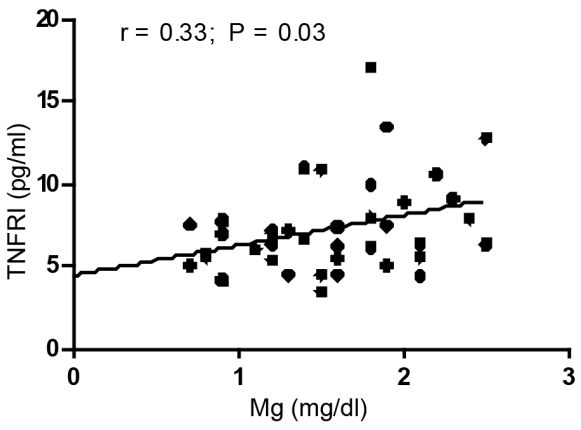

(b)

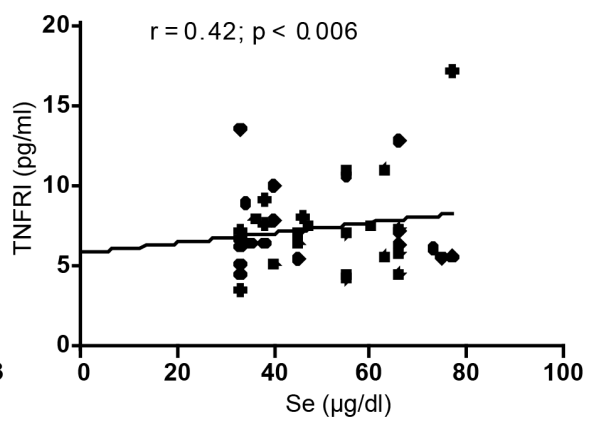

(c)

Figure 2. (a): 4 Spearman rank correlation between plasma levels of Magnesium $(\mathrm{Mg})$ tumour necrosis factor type- 1 (TNFR I) in HBV infected blood donors ( $n=40 ; r=0.33$, $\mathrm{P}=0.03)$; (b): Spearman rank correlation between plasma levels of Magnesium and tumour necrosis factor type -2 (TNFR II) in HBV infected blood donors $(n=40 ; r=0.33, P$ $=0.03$ ); Spearman rank correlation between plasma levels of Selenium (Se) and tumour necrosis factor type-2 (TNFR II) in HBV infected blood donors( $\mathrm{n}=40 ; \mathrm{r}=0.42, \mathrm{P}=$ $0.006)$.

absence of such risk factor in perceptible proportion (22.5\%) of the HIV-1 positive donors suggests acquisition of HIV-1 by other means like blood donation in unhygienic setup as pointed out in our earlier study [10]. Degree of consumption of alcoholic drinks was similar in all the subgroups of seropositive donors. A comparable proportion of seronegative control donors also revealed history of alcohol consumption which could be due to similarity in socioeconomic status between the seropositive subgroups and controls. The donors in the present study were repeat donors donating at multiple donation centres which provided us the opportunity of enrolling them at very early stages of HIV-1 or HBV or $\mathrm{HCV}$ infections based on recording of the interval between the point of detection of seropositivity in blood bank and preceding seronegative donation. This was further substantiated by the asymptomatic status, unaltered CD4 count, serum albumin and bilirubin levels as well as marginal alteration of liver enzyme profile comparable to control seronegative donors. Therefore, it may be presumed that the donors in the present study had pre-existing alterations in the trace element status prior to enrolment.

Trace elements play important roles in various components of both innate and acquired immune function [17]. Zinc promotes the growth, maturation and 


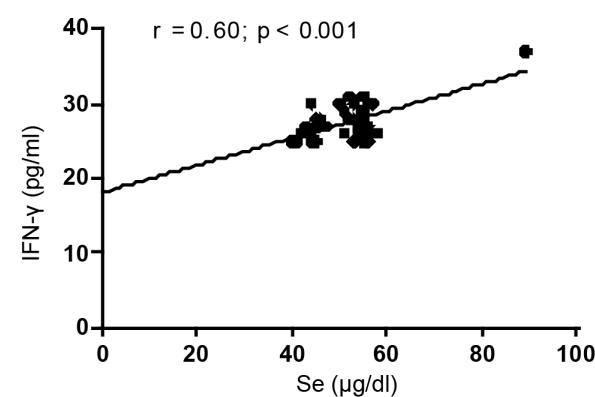

(a)

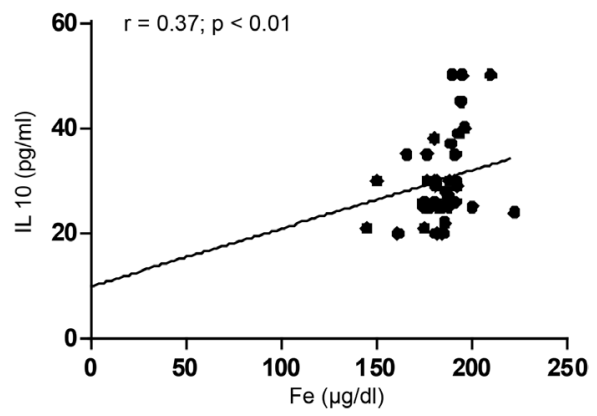

(c)

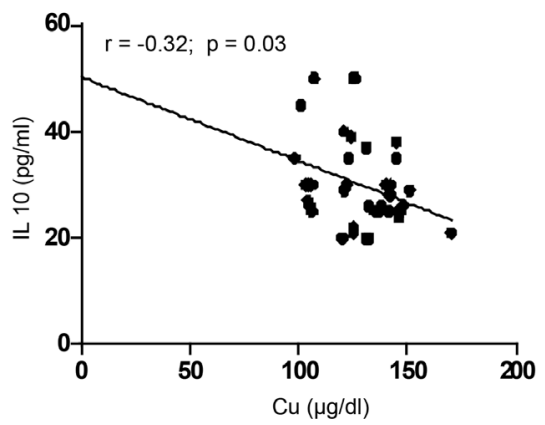

(e)

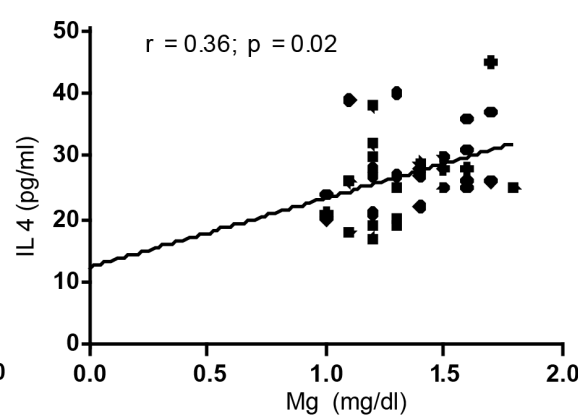

(b)

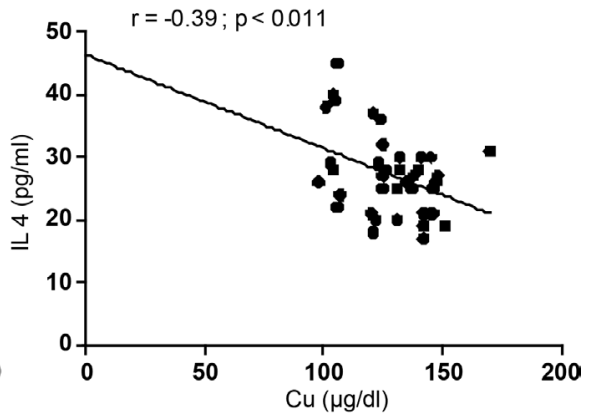

(d)

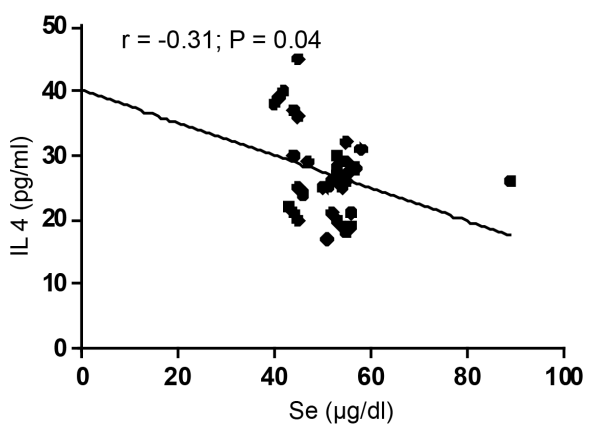

(f)

Figure 3. (a): Spearman rank correlation between plasma levels of Selenium (Se) and IFN gamma (IFN- $\gamma$ ) in HCV infected blood donors $(\mathrm{n}=40 ; \mathrm{r}=0.60, \mathrm{P}<0.001)$; (b): Spearman rank correlation between plasma levels of Magnesium $(\mathrm{Mg})$ and interleukin 4 (IL-4) in HCV infected blood donors $(n=40 ; r=0.36, P=0.02)$; $(c)$ : Spearman rank correlation between plasma levels of Iron (Fe) and interleukin 10 (IL-10) in HCV infected blood donors $(\mathrm{n}=40 ; \mathrm{r}=0.37, \mathrm{P}=0.01)$; (d): Spearman rank correlation between plasma levels of Copper $(\mathrm{Cu})$ and interleukin 4 (IL-4) in HCV infected blood donors $(n=40 ; r=-0.39$, $\mathrm{P}=0.01)$; (e): Spearman rank correlation between plasma levels of Copper $(\mathrm{Cu})$ and interleukin 10 (IL-10) in HCV infected blood donors $(\mathrm{n}=40 ; \mathrm{r}=-0.32, \mathrm{P}=0.03$ ); (f): Spearman rank correlation between plasma levels of Selenium (Se) and interleukin 4 (IL-4) in HCV infected blood donors ( $\mathrm{n}=40 ; \mathrm{r}=-0.31, \mathrm{P}=0.04)$.

activity of numerous immune cells, such as B and T lymphocytes and natural killer cells [18] and functions as a signalling molecule for defence cells [19]]. Zinc deficiency may also be accompanied by an imbalance of Th1 and Th2 cell function resulting in dysregulated resistance to infection [20]. Selenium (Se) is an essential micronutrient that affects optimal immune responses. Through its incorporation into selenoproteins, Se is involved in regulating oxidative stress, 
redox, and other crucial cellular processes in nearly all tissues and cell types, including those involved in innate and adaptive immune responses [21]. The measurement of trace elements especially viz, Se and $\mathrm{Zn}$ has been considered to predict disease progression in many viral infections e.g. HIV-1, HBV and HCV [9] [22] [23]. Iron plays important roles in anti-microbial host responses, firstly by synergistic effects towards anti-microbial radical formation [24] and secondly by directly altering immune cell proliferation and anti-microbial immune effecter pathways [25]. Conversely, excess iron promotes the formation of intracellular free radicals, which can cause oxidative damage [26]. Requirement of copper for optimal innate immune response has been demonstrated in animal models [27] and cell culture models using mouse macrophages [28], where the effects could be reversed by administration of $\mathrm{Cu}$. Nitric oxide (NO), an important mediator of intracellular killing of microbes, is degraded during copper deficiency [29]. Some of the recent research showed that interleukin-2 induced $T$ cell proliferation is reduced even in marginal copper deficiency [30]. Magnesium acts as a cofactor for immunoglobulin synthesis, immune cell adherence, antibody-dependent cytolysis and macrophage response to lymphokines.

Present study showed significantly depressed plasma levels of $\mathrm{Zn}, \mathrm{Se}, \mathrm{Fe}, \mathrm{Mg}$ and $\mathrm{Cu}$ in blood donors infected with HIV-1. Zinc is a component of HIV-1 nucleocapsid proteins and is used for gene expression, multimerization and integration in HIV-1 and this may explain the low plasma zinc levels observed in our study [31]. Low level of selenium in our study is in agreement with the view that HIV-1 requires large amount of selenium for its replication in the cell, which could deplete host level of selenium [7] and such decline in Se status has been reported to occur even in early stage of disease when malnutrition or mal-absorption cannot be a factor [22]. The Se deficient HIV-1 infected patients are nearly 20 times more likely to die from HIV related causes than those with adequate selenium levels [32]. Under low selenium conditions, increased oxidative stress and apoptosis activate the virus, which replicate at higher rates to escape from a dying cell [33]. Experimental evidence had shown that serum iron may decline in early asymptomatic HIV infection probably because of impaired absorption although they may however increase with progression of the disease as iron accumulates in the macrophages and other cells [34]. Depleted serum $\mathrm{Mg}$ concentration in early HIV-1 infection has been linked with common complaints of lethargy, weakness fatigue and decreased mentation in HIV infection [35]. Reduced level of $\mathrm{Cu}$ observed in our study could be due to reduction in the synthesis of ceruloplasmin by liver, possibly associated with HIV-1 infection [36].

The plasma trace element status in both HBV and HCV infected blood donors in the present study showed significantly low level of $\mathrm{Zn}$, Se and Mg concentrations and elevated level of $\mathrm{Cu}$ and $\mathrm{Fe}$ as compared to seronegative controls which is in agreement with the study by Hatano et al., [23] as well as by Kalkan et al., [37]. Studies have shown that lower concentration of selenium in the serum and erythrocytes in hepatitis B and C patients [38] [39] responds poorly to 
bacterial and viral infections leading to faster progression of both HBV and HCV infections [40] [41]. Reduced levels of selenium can be explained by the fact that selenium is used as a co-factor for glutathione peroxidise (GPX) enzyme. Se-dependent GPX and anti-oxidative ability are linked with reduced level of selenium micronutrient levels, although HCV infection has been reported to be potent in inducing oxidative stress suggesting that this mechanism is unique to this virus [42]. Elevated plasma copper levels in HBV and HCV as observed in the present study is considered to be due to redox process and oxidative stress [43]. Elevated level of Fe observed in the present study could reflect interruption of Fe metabolism during acute stage resulting into increased accumulation in liver [44]. It has been shown that hepatitis B surface antigen (HbsAg) positive cases have decreased magnesium levels in the serum suggesting the reflection of defence strategies by the organism [45].

The present study demonstrated a significantly low level of Th1 type of cytokines (IL- 2 and IFN- $\gamma$ ) in blood among HIV-1 infected group when compared to seronegative controls, while the Th2 type of cytokines i.e. (IL-4 and IL-10) remained unaltered. Many reports describe a shift from Th1 to Th2 cytokine profile during the progression of HIV-1 disease [46] [47]. There are numerous reports documenting association of imbalance of Th1 and Th2 categories of cytokines leading to disease progression in HIV, HBV and HCV infection [48] [49] [50]. It is generally accepted that qualitative defect in $\mathrm{T}$ cell function in terms of change in plasma cytokine profile from Th1 dominant to Th2 dominant can be evident before quantitative decline in $\mathrm{CD} 4+\mathrm{T}$ lymphocyte count at the asymptomatic stage of HIV infection [48]. An ongoing progression of HIV-1 infection in our group of asymptomatic HIV-1 infected blood donors was further evident from raised levels of immune activation markers i.e. TNF- $\alpha$ and sTNFR levels as reported in many studies [51] [52].

Both HBV and HCV infections in the present study showed dominance of Th2 category of cytokines and elevation of immune activation markers. It could be hypothesized that these donors were likely to be future potential persistent carriers for both these infections [53] [54], since balance between immunostimulatory and inhibitory cytokines has been shown to prolong inflammation leading to chronicity of liver disease in both these infections [54]. Patients with $\mathrm{HBV}$ and HCV infection have been reported to be characterterized by elevated plasma levels of TNF- $\alpha$, TNFR I and TNFR II as well as TNF- $\alpha$ production by in vitro [55] [56].

The present study showed a significant positive correlation between depression of $\mathrm{Zn}$ and $\mathrm{Cu}$ levels and Th1 type of cytokines in HIV-1 infection which is in agreement with studies [57] [58] showing that intracellular deficiency of $\mathrm{Zn}$ and $\mathrm{Cu}$ can lead to decrease in the synthesis and secretion of Th1 type of cytokines i.e. IL-2. Further, transcriptional activity of the IL-2 gene is suppressed in Zinc and $\mathrm{Cu}$ deficiency when $\mathrm{T}$ cells are treated with phytohemaglutinin or phorbolmyristate acetate [59].

It has been shown that in $\mathrm{Zn}$ deficiency generation of IL- 2 and IFN- $\gamma$ are de- 
creased where as the production of Th2 type of cytokines IL-4 and IL-10 are not affected [60]. A positive correlation between low level of $\mathrm{Cu}$ and depression in Th1 cytokine IL-2 level observed in our study is in agreement with the findings reported by Prasad [61], who demonstrated impaired secretion of IL-2 receptor (a marker of early $\mathrm{T}$ cell activation) by peripheral blood mononuclear cells from healthy subjects receiving a low $\mathrm{Cu}$ diet. Negative correlation of $\mathrm{Zn}$ with TNFR 1 in HIV-1 infected plasma samples of blood is consistent with the study of Prasad [60], who reported decreased plasma $\mathrm{Zn}$ to be associated with increased plasma oxidative stress markers and increased generation of inflammatory cytokines.

Positive correlation between Se with IFN- $\gamma$ in HCV infection observed in the present study has been demonstrated in mouse model experiments [6], where mice fed with deficient selenium diet resulted in decrease in interferon gamma levels in serum while positive correlation between Fe and IL-10 corroborate with the study of Baum et al. [8] who have shown that increased iron transferritin saturation (TS) is significantly associated with elevated Th2 cytokine profile in HCV positive patients. The positive correlations between Mg and IL-4 in our study substantiate the possibility that magnesium deficiency may affect antibody synthesis due to impaired signal to B cells by activated $\mathrm{T}$ helper cells [62].

Information on the inter-relationship between trace elements, cytokines and immune activation is limited to HIV-1 infection only [35], while there is hardly any such information available in HBV and HCV infections. There are numerous reports on alteration of trace elements in advanced stages of HIV, HBV and $\mathrm{HCV}$ infections, when interplay of multiple factors like decreased intake, impaired absorption and altered metabolism come into play [31] [37] [44]. However, data of such alterations in asymptomatic stage of these infections are lacking. Admittedly, however, our study to examine alteration of cytokines and activation markers was based on quantitation of plasma levels of cytokines and activation markers. More in depth studies like quantitation of mRNA expression of the cytokines and activation markers by in vitro cultured lymphocytes in presence of trace elements would have provided better insights into the alteration of these markers which we could not undertake due to resource constraints.

Nevertheless, the present report provides information on the association between trace element alteration and cytokine imbalance at early asymptomatic stage of HIV, HBV and HCV infections in absence of obvious protein calorie malnutrition that tends to point out that trace element alterations can exist at early asymptomatic stage since the donors in our study had unaltered parameters like BMI, protein intake, calorie intake, serum albumin levels comparable to control population.

\section{Conflict of Interest}

We declare that we have no conflict of interest.

\section{Acknowledgements}

This study was carried out by institutional support. 


\section{References}

[1] Shah, N., Shah, J.M., Jhaveri, P., Patel, K., Shah, C.K. and Shah, N.R. (2013) Sero Prevalence of HBV, HCV, HIV and Syphilis among Blood Donors at a Tertiary Care Teaching in Western India. Gujrat Medical Journal, 68, 35-39.

[2] DSACS Annual Report 2012.

[3] Clerici, M. and Shearer, G.M. (1994) The Th1-Th2 Hypothesis of HIV Infection: New Insights. Immunology Today, 15, 575-581. https://doi.org/10.1016/0167-5699(94)90220-8

[4] Jiang, R., Feng, X., Guo, Y., Lu Q., Hou, J., Luo, K. and Fu, N. (2002) T Helper Cells in Patients with Chronic Hepatitis B Virus Infection. Chinese Medical Journal, 115, 422-424.

[5] Abayli, B., Canataroglu, A. and Akkiz, H. (2003) Serum Profile of T Helper 1 and T Helper 2 Cytokines in Patients with Chronic Hepatitis C Virus Infection. The Turkish Journal of Gastroenterology, 14, 7-11.

[6] Melinda, A.B., Oriville, A. and Levender, J.H. (2003) Selenium Deficiency and Viral Infection. The Journal of Nutrition, 133, 1463S-1467S.

[7] Baum, M.K., Miguez-Burbano, M.J., Campa, A. and Shor-Posner, G. (2000) Selenium and Interleukins in Persons Infected with Human Immunodeficiency Virus Type 1. The Journal of Infectious Diseases, S1, S69-S73. https://doi.org/10.1086/315911

[8] Weiss, G., Umalauft, F., Urbanek, M., Herold, M., Lovevsky, M., Offner, F. and Gordeuk, V.R. (1999) Association between Cellular Immune Effecter Function Iron Metabolism and Disease Activity in Patients with Chronic Hepatitis C Virus Infection. The Journal of Infectious Diseases, 180, 1452-1458.

https://doi.org/10.1086/315052

[9] Selvraju, R., Ganapathi Raman, R., Narayanaswamy, R., Valliappan, R. and Baskaran, R. (2009) Trace Element Analysis in Hepatitis B Affected Human Blood Serum by Inductively Coupled Plasma Atomic Emission Spectroscopy (ICP-AES). Romanian Journal of Biophysics, 19, 35-42.

[10] Chattopadhya, D., Saha, K., Chakarbarty, A.K., Rao, K.N., Patil and Skdusaj, I.S. (1992) Nutritional Status of Children of Urban Leprosy Patients Staying at Preventoria Based on Biochemical Parameters. European Journal of Clinical Nutrition, 46, 885-895.

[11] CDC (2015) About Adult BMI, Division of Nutrition. National Centre for Chronic Disease Prevention and Health Promotion, Physical Activity and Obesity.

[12] Chattopadhya, D., Riley, L.W. and Kumari, S. (1991) Behavioural Risk Factors for Acquisition of HIV Infection and Knowledge about AIDS among Male Professional Donors in Delhi. Bull WHO, 69, 319-323.

[13] Aggarwal, V., Prakash, C., Yadav, S. and Chattopadhya, D. (1997) Prevalence of Transfusion Associated Infection in Multi Transfused Children in Relation to Mandatory Screening of Human Immunodeficiency Virus (HIV) Infection in Donated Blood. The Southeast Asian Journal of Tropical Medicine and Public Health, 28, 699-706.

[14] Mayo Clinic USA (2015) Information Sheet: Liver Function Tests; Test and Procedures.

[15] Baveja, U.K., Verghese, A., Chattopadhya, D. and Shivlal (2008) Evaluation of Levels of p24 Antigen in HIV/AIDS Cases and Correlation with CD4 T Cell Counts. JIACM, 9, 103-107. 
[16] Rakhara, G., Masih, D., Vats, A., Verma, S.K., Singh, V.K., Kirar, V., Archana, S., Mallika, M. and Som, N.S. (2015) Copper, Iron, Zinc and Magnesium Status of Physically Active Young Indian Males. IOSR Journal of Sports and Physical Education, 2, 25-32.

[17] Wintergerst, E.S., Maggini, S. and Hornig, D.H. (2007) Contribution of Selected Vitamins and Trace Elements to Infection. Annals of Nutrition and Metabolism, 51, 301-323. https://doi.org/10.1159/000107673

[18] Shepherd, R.J. and Shek, P.W. (1998) Immunological Hazards from Nutritional Imbalance in Athletes. Exercise Immunology Review, 4, 22-48.

[19] Haase, H. and Rink, L. (2009) The Immune System and the Impact of Zinc during Ageing. Immunity \& Ageing, 6, 9. https://doi.org/10.1186/1742-4933-6-9

[20] Shankar, A.H. and Prasad, A.S. (1998) Zinc and Immune Function, the Biological Basis of Altered Resistance to Infection. The American Journal of Clinical Nutrition, 68, 447-463.

[21] Gromer, S., Eubel, J.K., Lee, B.L. and Jacob, J. (2005) Human Selenoproteins at a Glance. Cellular and Molecular Life Sciences, 62, 2414-2437.

https://doi.org/10.1007/s00018-005-5143-y

[22] Rockstroh, J.K., Rao, G.S., Kreuzer, K.A., Spengler, U. and Sauerbruch, T. (1997) Serum Selenium Verses Lymphocyte Subsets and Markers of Disease Progression and Inflammatory Response in Human Immunodeficiency Virus-Infection. Biological Trace Element Research, 56, 31-41. https://doi.org/10.1007/BF02778982

[23] Hatano, R., Ebara, M., Fukuda, H., Yoshikawa, M., Sugiura, N., Kondo, F., Yukawa, M. and Saisho, H. (2000) Accumulation of Copper in Liver and Hepatic Injury in Chronic Hepatitis C. Journal of Gastroenterology and Hepatology, 15, 786-791. https://doi.org/10.1046/j.1440-1746.2000.02199.x

[24] Koskenkorva-Frank, T.S., Weiss, G., Koppenol, W.H. and Burckhardt, S. (2013) The Complex Interplay of Iron Metabolism, Reactive Oxygen Species, and Reactive Nitrogen Species: Insights into the Potential of Various Iron Therapies to Induce Oxidative and Nitrosative Stress. Free Radical Biology \& Medicine, 65, 1174-1194.

[25] Nairz, M., Schroll, A., Sonnweber, T. and Weiss, G. (2010) The Struggle for Iron-A Metal at the Host-Pathogen Interface. Cellular Microbiology, 12, 1691-1702. https://doi.org/10.1111/j.1462-5822.2010.01529.x

[26] Cardier, J.E., Romano, E. and Soyano (1995) A Lipid Peroxidation and Changes in T Lymphocyte Subsets and Lymphocyte Proliferative Response in Experimental Iron Overload. Immunopharmacology and Immunotoxicology, 17, 705-717. https://doi.org/10.3109/08923979509037190

[27] Subashchandrabose, S., Hazen, T.H., Brumbaugh, A.R., Himpsl, S.D., Smith, S.N., Ernst, R.D., Rasko, D.A. and Mobley, H.L. (2014) Host-Specific Induction of Escherichia coli Fitness Genes during Human Urinary Tract Infection. Proceedings of the National Academy of Sciences, 111, 18327-18332. https://doi.org/10.1073/pnas.1415959112

[28] White, C., Lee, J., Kambe, T., Fritsche, K. and Petris, M.J. (2009) A Role for the ATP7A Copper Transporting ATPase in Macrophage Bactericidal Activity. The Journal of Biological Chemistry, 284, 33949-33956. https://doi.org/10.1074/jbc.M109.070201

[29] Schuschke, D.A. (1997) Dietary Copper in the Physiology of Microcirculation. Journal of Nutrition, 127, 2274-2281.

[30] Percival, S.S. (1998) Copper and Immunity. The American Journal of Clinical Nu- 
trition, 67, 1064S-1068S.

[31] Mocchegiani, E., Veccia, S., Ancarani, F., Scalise, G. and Fabris, N. (1995) Benefit of Oral Zinc Supplementation as an Adjunct to Zidovudine (AZT) Therapy against Opportunistic Infections in AIDS. International Journal of Immunopharmacology, 17, 719-727.

[32] Baum, M.K., Short-Posner, G., Lai, S., Zhang, G., Lai, H. and Flether, M.A. (1997) High Risk of HIV-Related Mortality Is Associated with Selenium Deficiency. Journal of Acquired Immune Deficiency Syndromes and Human Retrovirology, 15, 370-374. https://doi.org/10.1097/00042560-199708150-00007

[33] Cowgill, G.M. (1997) The Distribution of Selenium and Mortality Owing to Acquired Immune Deficiency Syndrome in the Continental United States. Biological Trace Element Research, 56, 43-61. https://doi.org/10.1007/BF02778983

[34] Drakesmith, H. and Prentice, A. (2008) Viral Infection and Iron Metabolism. Nature Reviews Microbiology, 6, 541-542. https://doi.org/10.1038/nrmicro1930

[35] Shils, M.E. (1990) Magnesium. In: Braun, M.L., Ed., Present Knowledge in Nutrition, 6th Edition, International Life Sciences Institute, Washington DC, 224-232.

[36] Bogden, J.D., Kemp, F.W., Han, S., Li, W. and Bruening, K. (2000) Status of Selected Nutrients and Progression of Human Immunodeficiency Virus Type 1 Infection. The American Journal of Clinical Nutrition, 72, 809-815.

[37] Kalkan, A., Bulut, V., Avci, S., Celik, I. and Bingol, N.K. (2002) Trace Elements in Viral Hepatitis. Journal of Trace Elements in Medicine and Biology, 16, 227-230.

[38] Cavallo-Perin, P., Pacini, G., Cerutti, F., Bessone, A., Condo, C. and Sacchetti, L. (1995) Insulin Resistance and Hyperinsulinemia in Homozygous Beta-Thalassemia. Metabolism, 44, 281-286.

[39] Platis, O., Anagnostopoulos, G., Farmaki, K., Posantzis, M., Gotsis, E. and Tolis, G. (2004) Glucose Metabolism Disorders Improvement in Patients with Thalassaemia Major after 24-36 Months of Intensive Chelation Therapy. Pediatric Endocrinology Reviews, S12, 279-281.

[40] Jubbawy, A.A.H.S., Wtwt, M.A.A. and Shirafy, A.N.A. (2013) Correlation of Some Trace Elements and Chronic Hepatitis B Infections in Babylon. Journal of Natural Sciences Research, 3, 110-115.

[41] Conri, C., Fleury, B., Simonoff, M., Ducloux, G., Berdeu, B. and Moretto, P. (1988) Blood Selenium, Zinc and Copper in Alcoholism. Annales de Medecine Interne, 139, 138-139.

[42] Choi, J. and Ou, J.H. (2006) Mechanisms of Liver Injury III, Oxidative Stress in the Pathogenesis of Hepatitis C Virus. American Journal of Physiology. Gastrointestinal and Liver Physiology, 290, G847-G845. https://doi.org/10.1152/ajpgi.00522.2005

[43] Klein, D., Lichtmannegger, J., Finckh, M. and Summer, K.H. (2003) Gene Expression in the Liver of Long-Evans Cinnamon Rats during the Development of Hepatitis. Archives of Toxicology, 77, 568-575. https://doi.org/10.1007/s00204-003-0493-4

[44] Bsonkovsky, H.L., Banner, B.F. and Rothmanm, A.L. (1997) Iron and Chronic Viral Hepatitis. Journal of Hepatology, 25, 759-768. https://doi.org/10.1002/hep.510250345

[45] Kryska, A., Juszczyk, J., Bereszynska and Krajewski, P. (1990) Trace Elements: Zinc, Copper and Magnesium in Patients with Chronic Persisting Hepatitis-Evaluation of Changes during Therapy. Polski Tygodnik Lekarski, 10, 45-50.

[46] Clerici, M., Fusi, M.L., Ruzzante, S., Piconi, S., Biasin, M., Arienti, D., Trabattoni, D. and Villa, M.L. (1997) Type 1 and Type 2 Cytokines in HIV Infection-A Possi- 
ble Role in Apoptosis and Disease Progression. Annals of Medicine, 29, 185-188. https://doi.org/10.3109/07853899708999334

[47] Srikanth, P., Castillo, R.C., Sridharan, G., John, T.J., Zachariah, A., Mathai, D. and Schwartz, D.H. (2000) Increase in Plasma IL-10 Levels and Rapid Loss of CD4+ T Cells among HIV Infected Individuals in South India. International Journal of STD \& AIDS, 11, 49-51. https://doi.org/10.1258/0956462001914904

[48] Langerford, S.E., Ananworanich, J. and Cooper, D.A. (2007) Predictors of Disease Progression in HIV Infection: A Review. AIDS Research and Therapy, 4, 1-14. https://doi.org/10.1186/1742-6405-4-1

[49] Chang, J. and Levin, S.R. (2007) Immunopathogenisis of Hepatitis B Virus Infection. Immonology and Cell Biology, 85, 16-23. https://doi.org/10.1038/sj.icb.7100009

[50] Sobu, N., Nomura, T., Ito, S., Saso, K. and Joh, K. (2001) Th1 and Th2 Cytokine Profile and Their Relationship to Clinical Features in Patient with Chronic Hepatitis C Virus Infection. Journal of Gastroenterology, 36, 544-551. https://doi.org/10.1007/s005350170057

[51] Kalinkovich, A., Engelmann, H., Harpaz, N., Burstein, R., Barak, V., Kalickman, I., Hu, G.L. and Zhang, G. (1992) Elevated Levels of Soluble Tumour Necrosis Factor Receptors (sTNF-R) in Patients with HIV Infection. Clinical \& Experimental Immunology, 89, 351-355. https://doi.org/10.1111/j.1365-2249.1992.tb06961.x

[52] Norris, P.J, Pappalardo, B.L., Custer, B., Spotts, G., Hecht, F.M. and Busch, M.P. (2006) Elevations in IL10, TNF-Alpha and IFN-Gamma from the Earliest Point of HIV Type 1 Infection. AIDS Research and Human Retroviruses, 22, 757-762. https://doi.org/10.1089/aid.2006.22.757

[53] Fan, X.G., Liu, W.E., Li, C.Z., Wang, Z.C., Luo, L.X. and Tan, D.M. (1998) Circulating Th1 and Th2 Cytokines in Patients with Hepatitis C Virus Infection. Mediators of Inflammation, 7, 295-297. https://doi.org/10.1080/09629359890992

[54] Jacobson Brown, P.M. and Neuman, M.G. (2001) Immunopathogenesis of Hepatitis C Viral Infection: Th1/Th2 Responses and the Role of Cytokines. Clinical Biochemistry, 34, 167-171.

[55] Sheron, N., Lau, J., Daniels, H., Goka, J., Eddleston, A., Alexander, G.J.M. and Williams, R. (1991) Increased Production of Tumour Necrosis Factor Alpha in Chronic Hepatitis B Virus Infection. Journal of Hepatology, 12, 241-245.

[56] Kallinowski, B., Haseroth, K., Marinos, G., Hanck, C., Stremmel, W., Theilmann, L. and Singer, R. (1998) Induction of Tumour Necrosis Factor (TNF) Receptor Type p55 and p75 in Patients with Chronic Hepatitis C Virus (HCV) Infection. Clinical \& Experimental Immunology, 111, 269-277. https://doi.org/10.1046/j.1365-2249.1998.00469.x

[57] Dowd, P.S., Kelleher, J. and Guillou, P.J. (1986) T-Lymphocyte Subsets and Interleukin-2 Production in Zinc Deficient Rats. British Journal of Nutrition, 55, 59-69. https://doi.org/10.1079/BJN19860010

[58] Hopkins, R.G. and Failla, M.L. (1997) Cu Deficiency Reduces Interleukin-2 Production and mRNA Levels in Human T-Lymphocytes. Journal of Nutrition, 127, 257-262.

[59] Prasad, A.S., Bao, B., Beck, F.W.J. and Sarkar, F.H. (2001) Zinc Activates NF-kB in HUT-78 Cells. Journal of Laboratory and Clinical Medicine, 138, 250-256. https://doi.org/10.1067/mlc.2001.118108

[60] Prasad, A.S. (2000) Effect of Zn Deficiency on Th1 and Th2 Cytokine Shifts. The 
Journal of Infectious Diseases, 182, S62-S68.

[61] Prasad, A.S. (2008) Clinical Immunological Anti-Inflammatory and Antioxidant Roles of Zinc. Experimental Gerontology, 43, 370.

[62] Kubene, K.S. (1993) Role of Magnesium in Immunity. Journal of Nutritional Immunology, 2, 107-112. https://doi.org/10.1300/J053v02n03_07 


\section{Appendix}

Supplementary Table 1. CD4 Count, liver enzyme profile, albumin, energy intake, protein intake and $\mathrm{BMI}$ in various subgroups of seropositive donors.

\begin{tabular}{ccccc}
\hline & HIV-1 $(\mathrm{n}=40)$ & HBV $(\mathrm{n}=40)$ & HCV $(\mathrm{n}=40)$ & $\begin{array}{c}\text { Control } \\
(\mathrm{n}=40)\end{array}$ \\
\hline CD4 cells/ $\mu \mathrm{l}$ & $828 \pm 175$ & $844 \pm 149$ & $886 \pm 133$ & $907 \pm 159$ \\
ALT(U/L) & $32.6 \pm 30.1$ & $30.1 \pm 22.1$ & $27.7 \pm 21.9$ & $26.4 \pm 10.7$ \\
AST(U/L) & $28.7 \pm 18$ & $24.2 \pm 8.7$ & $22.8 \pm 9.2$ & $24.9 \pm 9.1$ \\
ALP(U/L) & $92.6 \pm 34.4$ & $88.9 \pm 33.9$ & $85.9 \pm 29.3$ & $79.8 \pm 20.6$ \\
Bilirubin (mg/dL) & $1.1 \pm 0.5$ & $1.2 \pm 0.7$ & $1.3 \pm 0.7$ & $1.0 \pm 0.20$ \\
Albumin(g/dL) & $4.0 \pm 0.5$ & $4.1 \pm 0.5$ & $4.3 \pm 0.5$ & $4.2 \pm 0.50$ \\
Energy (K cal/kg body weight) & $37.1 \pm 3.4$ & $36.6 \pm 2.9$ & $35.1 \pm 2.8$ & $38.3 \pm 0.42$ \\
Protein intake (gm/day) & $60.8 \pm 4.6$ & $59.4 \pm 5.3$ & $59.8 \pm 7.2$ & $61.5 \pm 4.7$ \\
BMI & $19.9 \pm 1.2$ & $20.9 \pm 2.8$ & $20.4 \pm 1.4$ & $21.1 \pm 4.2$ \\
\hline
\end{tabular}

Note: There was no statistical difference in the above parameters between HIV-1, HBV, HCV; infected donors and that of seronegative controls in multiple comparisons as well as in individual comparisons between the above subgroups ( by ANOVA).

Supplementary Table 2. Spearman rank correlations between plasma levels of trace elements and cytokines in HIV-1, HBV and HCV infected donors. (a) HIV-1; (b) HBV; (c) HCV.

(a)

\begin{tabular}{|c|c|c|c|c|c|c|c|c|}
\hline & & IL2 & IFN-y & IL-4 & IL-10 & TNF- $\alpha$ & TNFRI & TNFRII \\
\hline \multirow[t]{2}{*}{$\mathrm{Se}$} & $\mathrm{r}$ & 0.053 & 0.075 & 0.132 & 0.096 & -0.602 & 0.093 & 0.035 \\
\hline & $\mathrm{p}$ & 0.742 & 0.643 & 0.416 & 0.553 & 0.712 & 0.566 & 0.829 \\
\hline \multirow[t]{2}{*}{$\mathrm{Zn}$} & $\mathrm{r}$ & -0.142 & 0.339 & -0.092 & 0.290 & 0.145 & -0.318 & 0.228 \\
\hline & $\mathrm{p}$ & 0.379 & $0.033^{*}$ & 0.568 & 0.061 & 0.300 & $0.045^{\star}$ & 0.155 \\
\hline \multirow[t]{2}{*}{$\mathrm{Fe}$} & $\mathrm{r}$ & -0.067 & 0.269 & -0.200 & -0.167 & 0.169 & -0.026 & 0.133 \\
\hline & $\mathrm{p}$ & 0.690 & 0.093 & 0.215 & 0.301 & 0.296 & 0.870 & 0.411 \\
\hline \multirow[t]{2}{*}{$\mathrm{Cu}$} & $\mathrm{r}$ & 0.335 & -0.118 & 0.060 & 0.089 & -0.130 & 0.090 & -0.070 \\
\hline & $\mathrm{p}$ & $0.034^{*}$ & 0.468 & 0.700 & 0.582 & 0.017 & 0.597 & 0.666 \\
\hline \multirow[t]{2}{*}{$\mathrm{Mg}$} & $\mathrm{r}$ & -0.008 & -0.090 & 0.152 & -0.159 & -0.059 & 0.052 & 0.090 \\
\hline & $\mathrm{p}$ & 0.959 & 0.578 & 0.349 & 0.320 & 0.713 & 0.748 & 0.550 \\
\hline \multicolumn{9}{|c|}{ (b) } \\
\hline \multirow[t]{2}{*}{$\mathrm{Se}$} & $\mathrm{r}$ & 0.115 & -0.160 & 0.059 & 0.080 & 0.056 & 0.109 & 0.425 \\
\hline & $\mathrm{p}$ & 0.477 & 0.314 & 0.714 & 0.957 & 0.730 & 0.502 & $0.006^{*}$ \\
\hline \multirow[t]{2}{*}{$\mathrm{Zn}$} & $\mathrm{r}$ & 0.080 & 0.010 & -0.144 & 0.233 & -0.210 & -0.174 & -0.184 \\
\hline & $\mathrm{p}$ & 0.623 & 0.949 & 0.372 & 0.146 & 0.193 & 0.281 & 0.254 \\
\hline \multirow[t]{2}{*}{$\mathrm{Fe}$} & $\mathrm{r}$ & -0.096 & 0.001 & -0.013 & -0.055 & 0.080 & -0.025 & -0.009 \\
\hline & $\mathrm{p}$ & 0.557 & 0.993 & 0.933 & 0.732 & 0.623 & 0.874 & 0.954 \\
\hline \multirow[t]{2}{*}{$\mathrm{Cu}$} & $\mathrm{r}$ & 0.105 & -0.128 & 0.297 & 0.025 & 0.015 & 0.082 & -0.130 \\
\hline & $\mathrm{p}$ & 0.515 & 0.428 & 0.062 & 0.877 & 0.923 & 0.613 & 0.402 \\
\hline \multirow[t]{2}{*}{$\mathrm{Mg}$} & $\mathrm{r}$ & -0.153 & -0.110 & -0.049 & -0.270 & -0.060 & 0.330 & 0.331 \\
\hline & $\mathrm{p}$ & 0.344 & 0.498 & 0.702 & 0.091 & 0.710 & $0.030^{*}$ & $0.036^{\star}$ \\
\hline
\end{tabular}

*indicates significant correlation. 
(c)

\begin{tabular}{ccccccccc}
\hline $\mathrm{Se}$ & $\mathrm{r}$ & -0.123 & 0.600 & -0.317 & -0.110 & 0.218 & 0.275 & 0.275 \\
& $\mathrm{p}$ & 0.440 & $0.001^{\star}$ & $0.046^{*}$ & 0.490 & 0.170 & 0.063 & 0.081 \\
$\mathrm{Zn}$ & $\mathrm{r}$ & 0.024 & 0.221 & -0.171 & -0.140 & -0.016 & 0.267 & 0.267 \\
& $\mathrm{p}$ & 0.878 & 0.163 & 0.283 & 0.380 & 0.918 & 0.090 & 0.090 \\
$\mathrm{Fe}$ & $\mathrm{r}$ & -0.052 & 0.094 & 0.153 & 0.373 & 0.171 & -0.136 & -0.136 \\
& $\mathrm{P}$ & 0.745 & 0.555 & 0.338 & $0.017^{\star}$ & 0.283 & 0.393 & 0.393 \\
$\mathrm{Cu}$ & $\mathrm{r}$ & 0.105 & 0.201 & -0.395 & -0.326 & 0.004 & 0.310 & 0.310 \\
& $\mathrm{p}$ & 0.510 & 0.205 & $0.011^{*}$ & $0.039^{*}$ & 0.978 & 0.520 & 0.047 \\
$\mathrm{Mg}$ & $\mathrm{r}$ & 0.050 & 0.186 & 0.366 & -0.190 & -0.029 & 0.292 & 0.292 \\
& $\mathrm{P}$ & 0.752 & 0.242 & $0.020^{*}$ & 0.233 & 0.854 & 0.063 & 0.063 \\
\hline
\end{tabular}

*indicates significant correlation.

Submit or recommend next manuscript to SCIRP and we will provide best service for you:

Accepting pre-submission inquiries through Email, Facebook, LinkedIn, Twitter, etc. A wide selection of journals (inclusive of 9 subjects, more than 200 journals)

Providing 24-hour high-quality service

User-friendly online submission system

Fair and swift peer-review system

Efficient typesetting and proofreading procedure

Display of the result of downloads and visits, as well as the number of cited articles Maximum dissemination of your research work

Submit your manuscript at: http://papersubmission.scirp.org/

Or contact jbm@scirp.org 